\title{
Article \\ Two Obstacle Factors for Technological Standardization: The Viewpoint of Technological Frame
}

\author{
Yoshiaki Fukami ${ }^{1,2}$ (D)
}

1 Cyber Civilization Research Center, Global Research Institute, Keio University, 2-15-45 Mita, Minato, Tokyo 108-8345, Japan; yofukami@sfc.keio.ac.jp or yoshiaki.fukami@gakushuin.ac.jp

2 Department of Management, Faculty of Economics, Gakushuin University, 1-5-1 Mejiro, Toshima, Tokyo 171-8588, Japan

check for

updates

Citation: Fukami, Y. Two Obstacle Factors for Technological Standardization: The Viewpoint of Technological Frame. Standards 2022, 2,1-13. https://doi.org/10.3390/ standards2010001

Academic Editor:

Monica Scannapieco

Received: 15 August 2021

Accepted: 24 November 2021

Published: 24 December 2021

Publisher's Note: MDPI stays neutral with regard to jurisdictional claims in published maps and institutional affiliations.

Copyright: (C) 2021 by the author. Licensee MDPI, Basel, Switzerland. This article is an open access article distributed under the terms and conditions of the Creative Commons Attribution (CC BY) license (https:// creativecommons.org/licenses/by/ $4.0 /)$.
Abstract: The concept of the Internet of Things (IoT), which is an architecture in which devices supplied by various firms and services operated by distributed organizations exchange data, has been adopted in an increasing number of situations. While there are cases in which a small number of limited organizations collaborate on certain ecosystems based on proprietary specifications, the development of open standards is increasingly important for building scalable ecosystems because of the introduction of the concepts of Industry 4.0 and Society 5.0. Under these circumstances, there are two types of barriers to standardization. One barrier is the lack of shared frames for architectural design. The other barrier is the lack of awareness of the need for scalability. In this paper, we analyze the factors underlying these two barriers and discuss the path towards breakthroughs.

Keywords: collective technological frame; craftspersonship; ecosystem; platform; innovation; Internet of Things; smart city; connected industry; Industry 4.0; Society 5.0

\section{New Modes of Innovation and Standardization Research}

New modes of innovation that began to appear in the 2010s, such as smart cities and autonomous vehicles, function only when provided with mashed up data generated by diverse sensor devices via the Internet and the functioning of those modes varies based on processing results. This situation can only be attained when various firms and services operated by distributed organizations exchange data in real time by adopting the concept of the Internet of Things (IoT). The concept of implementing new services with the realtime processing of big data by an autonomously developed algorithm through artificial intelligence (AI) has been named Industry 4.0 and Society 5.0, i.e., concepts which are promoted by governments and companies worldwide. Four design principles have been identified as integral to Industry 4.0, namely, interconnection, information transparency, technical assistance, and decentralized decisions [1], and this concept has encouraged data distribution and sharing among distributed manufacturers.

The Connected Industry that is designed as part of Society 5.0, which aims to innovate society as a whole [2], aims to leverage IoT technology in a wider range of five priority areas: "manufacturing and robotics", "plant/infrastructure safety management", "automated driving and mobility services", "biotechnologies and materials", and "smart life" [3]. The Japanese Industrial Standards Committee (JISC) has proposed a specification based on Society 5.0 titled "Gap analysis for standardization of sustainable and human-centred societies enabled with cyber physical systems" for an International Workshop Agreement (IWA 39) [4]. This focus on a "human-centred" society is one of the core values of Society 5.0.

Many firms, such as Amazon [5,6], have opened application programming interfaces (APIs) for their own business models [7], which constitute the API economy [8]. The API economy consists of data with different specifications for each data provider. Few data providers focus on interoperability among data from different firms. Therefore, data aggregators, brokers, and service providers have emerged to allow for the utilization of 
data from different sources $[9,10]$. There have been many information silos, which have been barriers to the realization of Industry 4.0 and Society 5.0.

On the other hand, to develop services utilizing various sources of data on the city OSs used for smart cities, interoperability among such data is required. The development of open standards is increasingly important for building scalable innovation ecosystems [11]. Even if the number of devices connected to the Internet increases, big data that can be analyzed will not be produced unless the data generated by devices are integrated. Building an ecosystem where compatible data are generated, shared, and utilized by each device is necessary to create sustainable services. There have already been several attempts made by governments to achieve mutual accessibility of data, such as Germany's Industrial Data Spaces and the Government of Japan's Society 5.0 smart reference architecture. Private consortia such as the Industrial Internet Consortium (IIC) and standards bodies such as the IEEE [12] are also engaged in the process of formulating standard technical specifications related to the IoT. However, data exchange ecosystems and smart cities based on standard technical specifications remain in the proof-of-concept stage.

To realize compatibility among distributed data resources, there must be a common syntax and vocabulary as well as other specifications. However, different industries and regions may use the same concept but employ different terminology. Even given the same temperature data, the accuracy required differs greatly between machine part manufacturing lines and medical examinations. Operational differences among diverse stakeholders are a major impediment to standardization based on the concept of IoT. In an era when an unspecified number of devices are not interconnected via the Internet, it is sufficient if mutual availability among devices is realized within a specific company or within the same industry, a situation which would be sufficient for each specific industry or use case. Standardization has been implemented. When only a few devices were interconnected, it was sufficient for most services to function without interoperability among distributed and diversified devices. Therefore, most compatibility standards are set within industries and for specific use cases. Working groups in many organizations devoted to standard development have developed standards for specific industries and domains. However, the same data, such as footprints, are utilized for multiple unrelated applications, such as mobility services and energy management, in the coordination of the city OSs used for smart cities. Companies and organizations that design hardware and services for a variety of purposes must overcome contextual differences to achieve mutual availability in the era of the IoT.

Moreover, these standards tend to prevent innovation [13] because they function by reducing the variety of goods [14]. Moreover, excess inertia locks standardized specifications into previously widespread specifications [15]. Interoperability encourages data integration among diversified sources. At the same time, standards prevent data owners from changing their original or industry-specific specifications. Standards make existing businesses, which have been designed according to industry-specific rules, more efficient. However, they also interfere with the innovation through new cross-industry data transactions.

While these theories emerge primarily from the field of economics, a socio-technical system approach is also needed to discuss standardizations related to the IoT and smart cities that affect all areas of life. The socio-technical system approach shows the relation between technical and social systems and demonstrates that their interplay is essential for technology development success [16].

There are two types of barriers to standardization in building ecosystems with massive data exchanges in the IoT era. One barrier is the lack of shared frames for architectural design. The other barrier is the lack of awareness of the need for scalability. In this paper, we analyze the factors underlying these two barriers and discuss the path towards breakthroughs. 


\section{The Lack of Shared Frames for Architectural Design}

\subsection{City OS and Standards as a Platform}

Many services developed in the IoT era, such as smart cities and mobile services, are provided on platforms such as smartphone OSs and city OSs. In short, the design of services is a complementary good for ecosystem platforms. An OS is designed as a core component in systems, and an API, the interface design with other components, defines the functions of the entire system. The concept of Next Generation Service Interfaces (NGSI) is one of the core technical specifications of Fiware (Fiware official website: https: / /www.fiware.org/developers/ accessed on 8 August 2021), which is a city OS popular in Europe. The NGSI-LD, an updated NGSI data model incorporating the concept of linked data, has been standardized by the European Telecommunications Standardization Institute (ETSI) (GS CIM 009-V1.1.1-Context Information Management (CIM); NGSI-LD API https://www.etsi.org/deliver/etsi_gs/CIM/001_099/009/01.01.01_60/gs_CIM009 v010101p.pdf accessed on 8 August 2021). Therefore, API specification standards influence the functionality and competitiveness of the entire ecosystem.

Not all standards play a role of platform [17]. However, NGSI-LD in Fiware is a typical case of a standard used as a platform. Such specification functions as a set of standards for providing commonly required functions $[18,19]$. The APIs of Fiware are public standard specifications developed by the European Commission, and at the same time, Fiware itself is an open-source software developed by a variety of organizations and individuals. Members of the Fiware Foundation include public institutions, private companies, and private individuals. Forms of cooperation between platformers and partners are determined by the specifications of the API. The API and other resources are provided to partners and referred to as boundary resources [20].

Development of Fiware is conducted on GitHub, which is a popular web service for collaborative software development. Therefore, it is easy to participate in development activities and to propose functions and codes to be added. Even if the required functions are agreed upon among participants, it is not easy to reach consensus in the process of developing implementation methods and specification details. Technology development is defined as the process, tasks, and decisions that firms embrace to select and integrate a new or existing technology into a final product or service [21,22]. Smart cities are a form of digital transformation in community management. Digital transformation refers to a revolution in how things, including products and services, operate and how people interact with one another $[5,23]$. Moreover, applications applied to technologies will be newly discovered as they become more widespread [24]. The diversity of participants and the ease of making proposals lead to increased coordination costs because the overall picture of smart cities and the functions to be developed by each participant may be diverse.

In an ecosystem with various stakeholders involved in operation, compatibility of the data processed by each application is essential for various applications to work together on city OSs. Therefore, it is necessary for the API specifications of city OSs to be uniformly compliant among stakeholders as a standard. Moreover, any standards are developed by agreement among stakeholders. Agreement can be achieved only with a common technological frame. Upgrading may involve changes in the concept and role of specification. To realize changes in standard specifications, a shared technological frame $[25,26]$ among stakeholders is necessary. The upgrade of Hyper Text Markup Language (HTML) at the World Wide Web Consortium (W3C) is a typical example of a framing contest in standardization.

\subsection{HTML Update as a Framing Contest}

The ideal role and function of the core module depends on the interests of the stakeholders that comprise ecosystems. If an ecosystem is not dictated by a particular organization, keystone [27], or platform leader [28], there may be competitions concerning who takes the initiative for the design of the platform when trying to revamp the ecosystem by 
upgrading an open platform. In other words, upgrading standards for designing platforms sometimes become races among technological frames $[25,26]$.

The concept of frame was originally used in social movement theory. To gain support, activists try to establish a collective frame [29] by making their own frames widely accepted. The scope indicated by "society" is not limited to one region or country. In other words, conflicts among frames are not limited to a single region and may develop into an international agenda, such as environmental issues [30] and international trade [31]. Therefore, the concept of frame has been applied by management scholars to analyze drastic changes in market structure (such as [32-34]).

From the viewpoint of innovation and the evaluation of emerging technologies, in short, technological frame [25] or technology frame [26] has come to be an important factor for building business models, and cases such as cochlear implants [35], DTP and digitization of newspapers [36], and digital photography [37] have been analyzed.

The technological frame used may limit prospective applications of emerging technologies within organizations [25]. Bijker and Pinch [38] pointed out that any technological artifact is recognized differently in terms of its significance for each organization and interacts with each organization based on different contexts. Therefore, each organization establishes a different frame for any technological artifact. Such diversity causes differences among strategies for utilizing technologies [25]. Acha [26] pointed out that pass dependency causes such differences.

There may be more than two different frames for new technologies, such as when threats and opportunities are both present within the same organization. This coexistence is a framing contest [34].

\subsection{Competition and Cooperation for Standard Setting}

Not all standards play a role in platforms, but some do [17]. HTML, which used to be merely a mark-up language for stable documents, has transformed into a runtime environment for web applications. HTML5, one of the specifications proposed as a successor to HTML 4.01, can be regarded as a platform because it provides functions, such as certain APIs, commonly required for the operation of various web applications and realizes coordination among these functions $[18,19]$. HTML5, which is the newest version of W3C's standard, realizes "web applications", such as Google Spreadsheet instead of Microsoft Excel, thereby allowing applications such as spreadsheets to run on servers instead of on client hardware regardless of the type of browser used by the client. Multiple users editing one specific web application is a typical case of innovation through standardization. Web applications allow multiple users to edit a single file simultaneously. In addition, since the files are on the cloud, the user can work smoothly using multiple terminals regardless of whether he or she is at home, at work, or away. The innovation of web applications meets the demand caused by the COVID-19 epidemic for updates to operations, especially concerning collaborative practices.

A platform is a component commonly utilized by multiple complements $[19,28]$. The HTML5 predecessor specification, XHTML Module: Extensions to Form Controls, was first proposed in 2003. The following year, in 2004, the original concept of HTML5 was proposed by two browser vendors, Mozilla Foundation and Opera Software, but was officially rejected because there was a different upgrade plan.

W3C staff members, including Tim Berners-Lee, who serves as Director, and several member companies share the different technological frame of advanced HTML developed with eXtensive Markup Language (XML). It was Tim Berners-Lee's plan to use this technology to enhance the functionality of websites with XML technology. XML was widespread as a data format for machine processing at the time. The difference between the existing HTML and XHTML depends on whether or not the data consist of XML-based syntax. Therefore, the documents sent from servers in response to requests never change dynamically. Changes displayed to users on browsers occur only with new requests and the download of new documents (Figure 1). The technological frame of XHTML is to preserve 
the role of websites as stable documents, similar to existing HTML. On the other hand, HTML5 is designed as a runtime for web applications. HTML5 documents change dynamically without reloading through data transactions via application programming interfaces, such as documents used by native applications such as Microsoft Word (Figure 2).

HTML5 was supported by web content creators who did not need the new features of XHTML realized by XML technologies. XHTML was supported by companies providing solutions for enterprises (such as IBM) and researchers of markup languages, such as W3C staff like Tim Berners-Lee. At the beginning of the 21st century, two different technological frames for the web platform coexisted, and a collective technological frame had not yet been formed. In short, there was a typical framing contest at W3C.

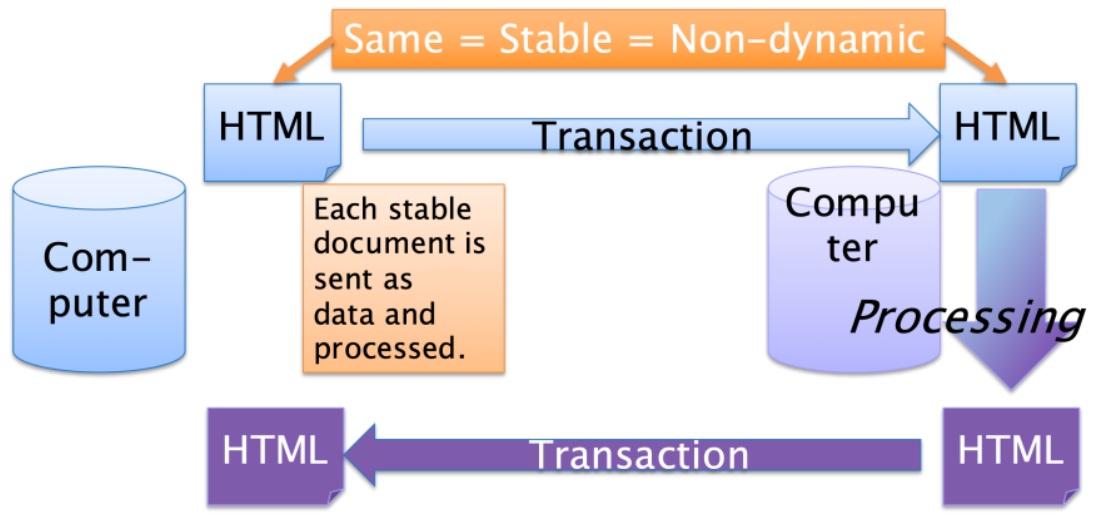

Figure 1. Concept of early HTML.

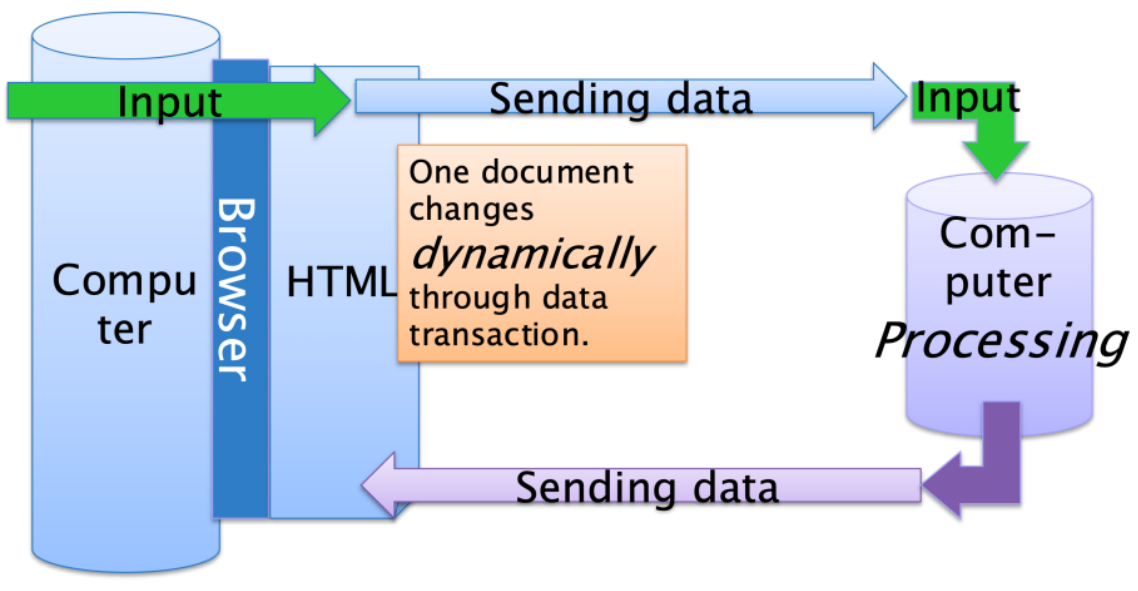

Figure 2. Concept of HTML5.

The result of this framing contest was the victory of HTML5, which was achieved by successfully gaining the support of members of the standards body and website developers and by implementing the implementation of HTML5 in Apple and Google products. HTML5 was welcomed by organizations and individual engineers both inside and outside the standards body. Moreover, Apple and Google joined the original proponents of HTML5, Mozilla Foundation and Opera Software, as advocates and actively promoted HTML5 to website developers. The concept of HTML5 has become a collective technological frame of the web platform ecosystem [39].

Ecosystem designs based on concepts such as IoT and smart cities tend to be enormous and involve diverse stakeholders. Sometimes, conflicting stakeholders must coexist within the ecosystem. In other words, it is difficult to avoid the coexistence and competition of multiple technology frames. Orlikowski and Gash pointed out that technological frames tend differ between engineers and end-users [25]. Engineers tend to focus on the technologies themselves rather than their use in specific contexts. On the other hand, users 
sometimes misunderstand and become confused by technologies. From the perspective of multisided market theory [40-42], it is important to form a collective technological frame among the diverse stakeholders that make up the ecosystem, such as engineers, end users, and residents. The question of how to form a collective technological frame among diverse and conflicting stakeholders has emerged as an important topic in standardization research.

\section{Trade-Offs between Scalability and Diversity}

\subsection{Standardization in the Industrial Internet and Social Change}

The concept of the Industrial Internet, in which all physical devices are connected to the Internet and operated by control based on data processing, has long been advocated. Studies on the digitalization of human operation in manufacturing have been conducted (e.g., [43].) The Industrial Internet Consortium (IIC) was founded in 2014 by AT\&T, Cisco, General Electric, IBM, and Intel. Google and other Silicon Valley companies are also developing many IoT-related technologies, products, and services.

In 2006, before the IIC, a cross-sectoral consortium was established; i.e., the Continua Health Alliance (CHA) was launched to develop a personal telehealth ecosystem [44]. The purpose of the CHA was to develop interoperability guidelines [45], and members of the organizations have contributed to standardization activities in multiple standard development organizations. The CHA has developed a complex e-health information communication ecosystem that consists of a specialized medical profile for ISO/IEEE 11073 interoperability, such as USB, Bluetooth, and ZigBee [46]. CHA activities are deployed in the limited field of healthcare, especially for long-term follow-up monitoring outside of medical institutions for patients with lifestyle-related diseases, and it is a successful example of a private sector project to establish a sustainable framework with a de-jure standard.

On the other hand, as mentioned at the beginning of this article, there are governmentled initiatives for sharing data not only among single applications but also among all types of devices, including manufacturing facilities, to achieve a digital transformation of the entire social economy, such as Industry 4.0 in Germany and Connected Industry in Japan. The German Industry 4.0 (Industrie 4.0) strategy was announced by the German government in 2011, and European activities for promoting the Industrial Internet have become widespread. Based on the concept of Society 5.0, Germany subsequently organized Platform Industrie 4.0 in 2013 and published Reference Architecture Model Industrie 4.0 (RAMI 4.0) (Platform Industrie 4.0 Reference Architectural Model Industrie 4.0 (RAMI4.0)—An Introduction. Retrieved from https:/ / www.plattform-i40.de/PI40/Redaktion/EN/Downloads/Publikation/ rami40-an-introduction.pdf? _blob=publicationFile\&v=7 accessed on 9 August 2021) in 2015 to improve the environment for the realization of Industrie 4.0.

The Japanese national government began to promote Connected Industry in 2017 (Ministry of Economy, Trade and Industry of Japan. (2017). "Connected Industries" Tokyo Initiative 2017. Retrieved from https: / / www.meti.go.jp/english/press/2017/pdf/1002 _004b.pdf accessed on 9 August 2021). After that, the Japanese government advocated Society 5.0, which promotes data utilization not only in the industrial field but also in society as a whole [2] and released Society 5.0 Reference Architecture. Japan's Ministry of Economy, Trade, and Industry has launched gBizID, a set of digital identification services (Ministry of Economy, Trade, and Industry of Japan. (2020). Provision of gBizIDs to Systems for Administrative Procedures in Local Governments and Other Organizations to Start. Retrieved from https:/ / www.meti.go.jp/english/press/2020/0805_002.html accessed on 11 August 2021), and developed Infrastructure for Multilayer Interoperability (IMI), a common vocabulary framework for data transaction among public and private sectors (Ministry of Economy, Trade and Industry of Japan. (n.d.). What is IMI. Retrieved from https://imi.go.jp/goi/imi-about-en/ accessed on 11 August 2021) based on the Basic Act on the Advancement of Public and Private Sector Data Utilization (Basic Act on the Advancement of Public and Private Sector Data Utilization retrived from the System of Japanese Law Transration of Ministry of Justice, Japan; http: / / www.japaneselawtranslation. go.jp / law / detail/?printID=\&id=2975\&re=01\&vm=02 accessed on 11 August 2021). 
Despite the existence of technical specifications prepared by the government and many experimental demonstrations of smart factories and smart cities, social implementation of standardization has not progressed well. While the activities of a private consortium led by a giant platform with significant market influence, such as Google or Intel, play a central role in creating implementation cases in the United States, much expense and time are needed to reach consensus and develop standards for the transformation of society and industrial structure with information technologies in Germany and Japan. The increase in and diversification of participants causes delays in the standardization process [47-49]. However, there are areas where the diversity of stakeholders is not the only barrier. The process of manufacturing, especially craftsmanship, is ongoing and has not been digitized.

In Japan, where the birth rate is declining and the population is aging, it is becoming difficult to hire and develop human resources that can personally inherit the tacit knowledge and skills used by craftsmen. In 2000, a round-table conference on manufacturing was established, which discussed the need for policies to promote technology succession. In Japan, the private sector has also established the Industrial Value Chain Initiative (IVI), which aims at social implementation of data distribution and control technology in manufacturing and distribution processes (What is IVI?-Industrial Valuechain Initiative https: / /iv-i.org/wp/en/about-us/whatsivi/ accessed on 11 August 2021). Both the public and private sectors have invested in the digitization of craftspersonship, interconnection among machinery, and reference architecture. They have also developed technological infrastructure and legal systems for data exchange. Nevertheless, the electronic accumulation and utilization of knowledge in the manufacturing industry has not progressed well. I maintain that there are hidden issues of standardization research involved in this case.

\subsection{Craftspersonship, Innovation, and Standardization}

There are several types of technologies that are targeted in the implementation of the Industrial Internet, i.e., electronic controls in manufacturing that are based on data collected and exchanged through the Internet. MacKenzie and Wajcman classified technology into three layers: (1) "physical objects or artifacts", (2) "activities or processes" and (3) "what people know as well as what they do" [50].

The digitization of the procedure, which originally involved manually collecting measurement data and operating based on numerical values, runs smoothly [51]. Digitization is relatively acceptable in areas where there is a strong need for automation, such as household appliances. Panasonic launched an electronically controlled coffee roaster, "Panasonic the Roast, AE-NR01", in 2017 in Japan. The roaster can download roasting profiles from the famous roaster, Naoki Goto. This process allows the consumers to enjoy the same roast as a famous roaster at home.

Panasonic released a smartphone application that allows users to create their own roasting profile in 2018. The machine and the application are used by multiple coffee shops and roasting companies. In the interview, three famous coffee shops and roasting companies used the machine for sample roasting in new product development. However, the use of electronic roasting profiles is limited to sample roasting (Interview with Tokado Coffee, Golpie Coffee, and Rec Coffee in PR article of Panasonic in Japanese. Retrieved from https: / / akatiti.net/articles/view / 416 accessed on 11 August 2021). The amount of beans that can be roasted at one time with AE-NR01 is $50 \mathrm{~g}$, which is too small to produce products for sale.

The batch of a commercial coffee roasting machine is at least a few kilograms. Figure 3 shows a small commercial roaster from a Japanese start-up roastery with a batch of $4 \mathrm{~kg}$. All preinstalled instruments are analogue. The digital timer, without Bluetooth and other communication modules, was attached after installation by the roastery. The roaster creates his original roasting profile by entering the temperature changes into an Excel spreadsheet each time (Figure 4). The batch of roasting for large-capacity models with an automatic control function and a temperature sensor is $10-70 \mathrm{~kg}$. However, the function of importing 
electronic roasting profiles is not implemented in such a commercial roasting machine with sensor control function.

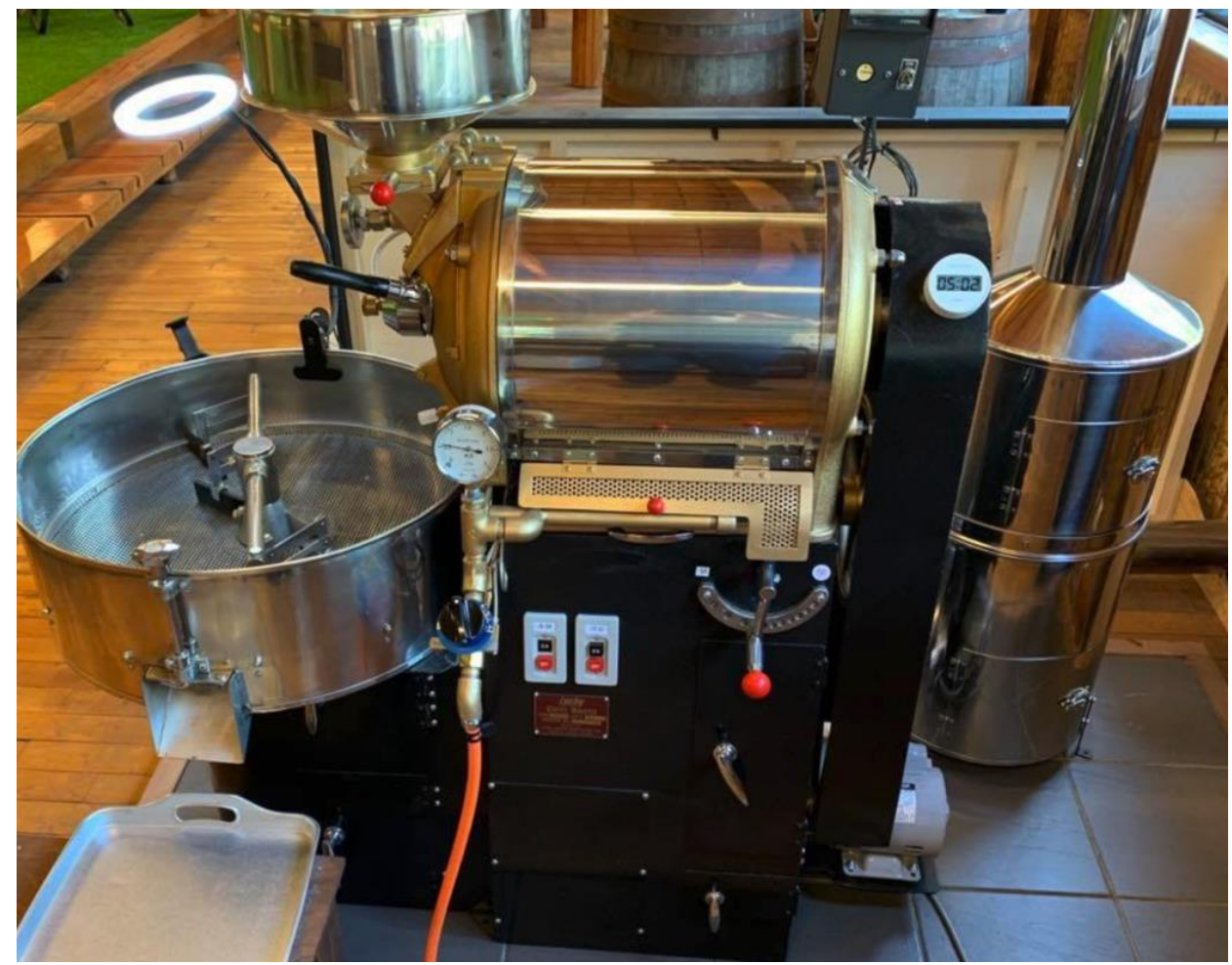

Figure 3. Small commercial roaster with a capacity of $4 \mathrm{~kg}$.

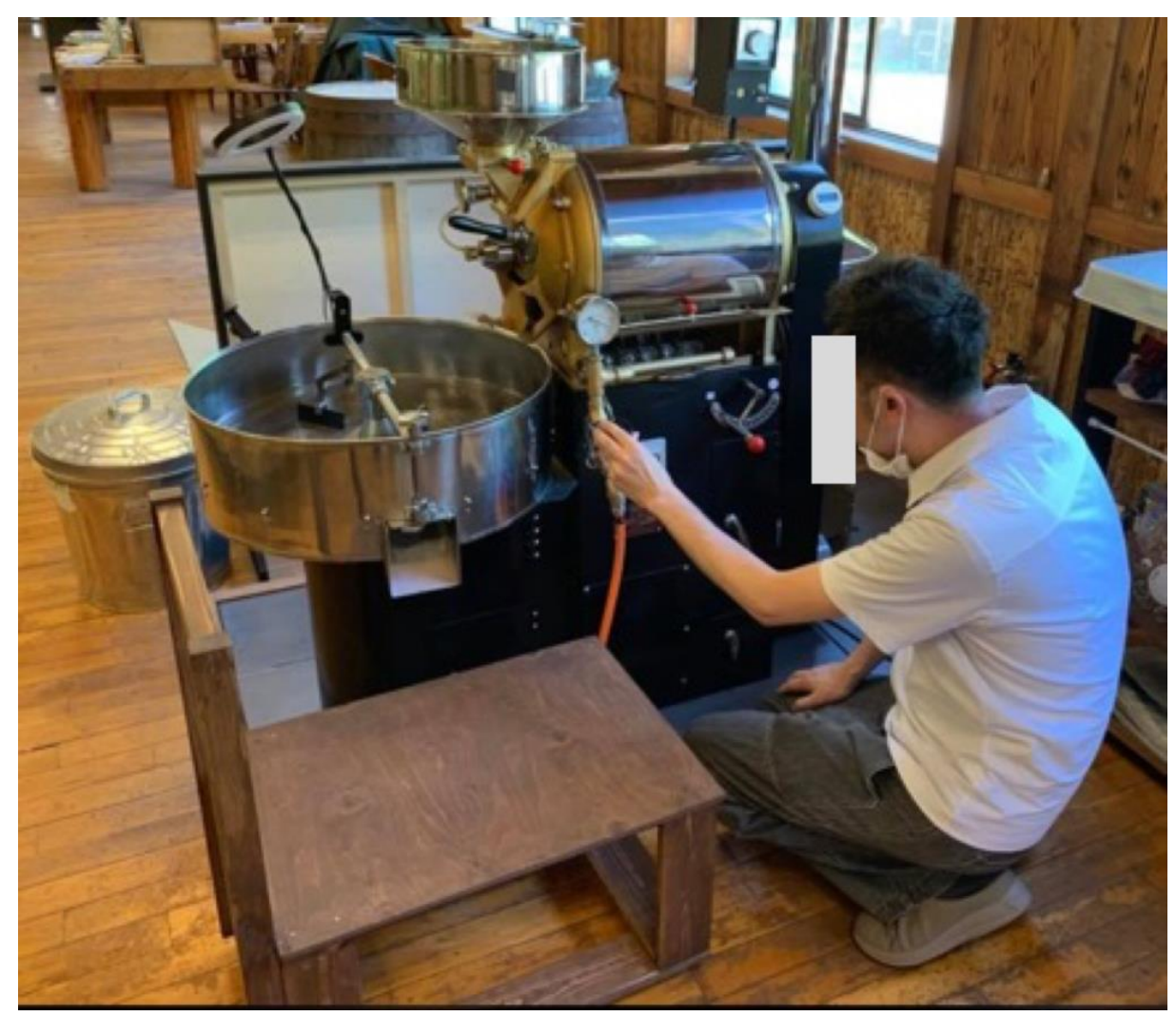

Figure 4. A roaster adjusting the heating power based on the analogue thermometer. 
The procedure for product development is determined as follows: a sample profile is created on a small capacity machine based on home use, and then the product is produced on a large capacity commercial machine. Therefore, it seems reasonable for the electronic profile information created by Panasonic's software to be imported directly to the commercial machine and then corrected to fit large commercial roasters. However, as of August 2021, it is not yet possible to exchange profiles between machines from Panasonic and those of other commercial vendors, such as Loring.

Coffee is an aromatic delicacy and scientific studies on coffee itself and additives such as milk [52-54] have been conducted. The extraction process is important [55]. However, roasting is also the most important factor affecting the aroma when drinking [56]. Therefore, the effect of roasting on aroma has also been analyzed [57-64]. Studies on sensing technology for roasting conditions are also being conducted [65].

Advances in preservation technology have made it possible to distribute roasted beans while preserving their aroma [66]. In other words, roasting is one of the most important factors in determining the market value of coffee, which is why many craftsmen have devised and refined roasting techniques. Utilizing these research results, high-precision control of coffee roasting is possible, and US manufacturers such as Loring have implemented such functions. However, profile data cannot be shared among devices, even those from the same manufacturers. It is natural to speculate that the barrier to data exchange is not technological.

One possible explanation for this fact is the diversity of cognitive frames discussed earlier in this paper. Sensory studies performed by cupping experts often use different expressions for the same condition in scientific measurements [67]. In addition, the vocabulary for taste expression is constantly being updated $[67,68]$. In other words, there is widespread belief within and outside the industry that sensing chemical component quantities and ratios alone is not sufficient to describe roasting techniques. From an engineering and scientific point of view, the difference in expression can be overcome by quantification of the measured component amounts.

Coffee is a luxury item and users have diverse tastes. In addition, products are often not selected based on clarified and quantified criteria. Coffee roasting techniques are perceived differently than those used in automated mass production processes. It is necessary to further understand the roasting technology itself.

Coffee, which has a variety of products linked to the personality of individual craftspersons, has a variety of taste and aroma evaluation vectors that compose the value provided. Some categories of technologies concern the integration of process and knowledge. Some of these kinds of technologies are sticky to the individual craftsperson. Sticky information is an important factor in innovation $[69,70]$. If stickiness is the key to competitiveness, then it is natural for craftspersons to hesitate to contribute to the digitalization of their skills and the standardization of shared data.

Coffee is not the only product category with these characteristics. Most foods have a particularly strong tendency towards such idiosyncrasy. In the cereal food market, the manual manufacturing method is becoming more popular, as artisan bread has become popular [71]. DeVore pointed out that technological development is influenced by norms and values in society [72]. Craftspersons have avoided pursuing scalability and standardizing technology in markets where brands that supply small quantities of highly unique and high-quality products are popular. Skolimowski pointed out that technology is a form of human knowledge [73]. If technical knowledge remains disparate and unsystematized, it is extremely difficult to integrate and standardize it, even if it is digitized. However, the concept of the IoT applies to all devices that operate in a standalone manner. Therefore, all technologies are subject to digitization and standardization. The diversity of procedures, classification, and vocabulary is not the only barrier to standardization in such industries.

Analysis of the case of coffee roasting profiles raises research questions whether the technology is evaluated to be standardized or not, and, if not, questions of how to foster such recognition are arising. 


\section{Conclusions}

A reduction in communication and information processing costs has led to ubiquitous sensors, creation of big data, generalization of artificial intelligence utilization, and realtime control of various kinds of systems. With these changes, all socio-economic activities are being updated by innovation through standardization in technology.

In an ecosystem composed of cyber-physical systems, all components are required to work together through shared data. Due to such changes in the situation, the following two research issues have emerged in the field of standardization. The first issue is how to foster a collective technological frame for core platforms. The other issue is how to establish scalability through standardization in areas where competitiveness as differentiation is pursued as craftspersonship. The former issue requires careful analysis of the process of consensus building among stakeholders with conflicting interests for the former, while the latter requires shifting the common perception of business models across a certain industry. Standardization research in the IoT era requires analysis not only of technology and institutional design but also of social structures within ecosystems and industries and changes in technological frames.

Both Industry 4.0 and Society 5.0 are in the process of spreading concepts and reference architecture. Each reference architecture has elements that realize data sharing and cooperation between organizations, such as an integration/data federation layer $[74,75]$. Only a few use cases and related technological specifications have already been implemented based on such policies. Therefore, verification of the issues examined in this paper is an issue for the future, which I would like to continue to analyze.

Funding: Funding has been received from the Japan Society for the Promotion of Science KAKENHI $20 \mathrm{H} 02384$.

Institutional Review Board Statement: This study was conducted according to the guidelines of Keio University.

Informed Consent Statement: Informed consent was obtained from all subjects involved in the study.

Data Availability Statement: Some public data will be made available upon the request to the authors.

Conflicts of Interest: The author declares no conflict of interest.

\section{References}

1. Hermann, M.; Pentek, T.; Otto, B.; Pentek, T. Design Principles for Industrie 4.0 Scenarios. In Proceedings of the 49th Hawaii International Conference on System Sciences, Koloa, HI, USA, 5-8 January 2016; p. 16. [CrossRef]

2. Narvaez Rojas, C.; Alomia Peñafiel, G.A.; Loaiza Buitrago, D.F.; Tavera Romero, C.A. Society 5.0: A Japanese Concept for a Superintelligent Society. Sustainability 2021, 13, 6567. [CrossRef]

3. Ministry of Economy, Trade and Industry of Japan. "Connected Industries" Tokyo Initiative; Ministry of Economy, Trade and Industry of Japan: Tokyo, Japan, 2017. Available online: https://www.meti.go.jp/english/press/2017/pdf/1002_004b.pdf (accessed on 15 August 2021).

4. ISO/IWA 39. The Gap Analysis for Standardization on Sustainable and Human-Centered Societies Enabled with Cyber Physical Systems; ISO: Geneva, Switzerland, 2020.

5. Nambisan, S.; Lyytinen, K.; Majchrzak, A.; Song, M. Digital Innovation Management: Reinventing Innovation Management Research in a Digital World. MIS Q. 2017, 41, 223-238. [CrossRef]

6. Evans, P.C.; Basole, R.C. Economic and Business Dimensions: Revealing the API Ecosystem and Enterprise Strategy via Visual Analytics. Commun. ACM 2016, 59, 26-28. [CrossRef]

7. Zachariadis, M.; Ozcan, P. The API Economy and Digital Transformation in Financial Services: The Case of Open Banking; Elsevier BV: Amsterdam, The Netherlands, 2017.

8. Tan, W.; Fan, Y.; Ghoneim, A.; Hossain, M.A.; Dustdar, S. From the Service-Oriented Architecture to the Web API Economy. IEEE Internet Comput. 2016, 20, 64-68. [CrossRef]

9. Immonen, A.; Palviainen, M.; Ovaska, E. Requirements of an Open Data Based Business Ecosystem. IEEE Access 2014, 2, 88-103. [CrossRef]

10. Janssen, M.; Zuiderwijk, A. Infomediary Business Models for Connecting Open Data Providers and Users. Soc. Sci. Comput. Rev. 2014, 32, 694-711. [CrossRef]

11. Granstrand, O.; Holgersson, M. Innovation Ecosystems: A Conceptual Review and a New Definition. Technovation 2020, 90-91, 102098. [CrossRef] 
12. IEEE Standard Association. IEEE Standards Activities in the Internet of Things (IoT); IEEE Standard Association: Piscataway, NJ, USA. Available online: https://standards.ieee.org/content/dam/ieee-standards/standards/web/documents/other/iot.pdf (accessed on 15 August 2021).

13. Baldwin, C.; von Hippel, E. Modeling a Paradigm Shift: From Producer Innovation to User and Open Collaborative Innovation. Organ. Sci. 2011, 22, 1399-1417. [CrossRef]

14. Farrell, J.; Saloner, G. Standardization and Variety. Econ. Lett. 1986, 20, 71-74. [CrossRef]

15. Farrell, J.; Saloner, G. Standardization, Compatibility, and Innovation. RAND J. Econ. 1985, 16, 70-83. [CrossRef]

16. Fuenfschilling, L.; Truffer, B. The Interplay of Institutions, Actors and Technologies in Socio-Technical Systems-An Analysis of Transformations in the Australian Urban Water Sector. Technol. Forecast. Soc. Chang. 2016, 103, 298-312. [CrossRef]

17. Cusumano, M. The Evolution of Platform Thinking. Commun. ACM 2010, 53, 32. [CrossRef]

18. Baldwin, C.Y.; Woodard, C.J. The Architecture of Platforms: A Unified View. In Platforms, Markets and Innovation; Gawer, A., Ed.; Edward Elgar Publishing: Cheltenham, UK, 2009; ISBN 9781848440708.

19. Meyer, M.; Utterback, J. The Product Family and the Dynamics of Core Capability. Sloan Manag. Rev. 1993, 34, $29-47$.

20. Ghazawneh, A.; Henfridsson, O. Balancing Platform Control and External Contribution in Third-Party Development: The Boundary Resources Model. Inf. Syst. J. 2013, 23, 173-192. [CrossRef]

21. Iansiti, M. How the Incumbent Can Win: Managing Technological Transitions in the Semiconductor Industry. Manag. Sci. 2000, 46, 169-185. [CrossRef]

22. Magistretti, S.; Dell'Era, C.; Verganti, R. Searching for the Right Application: A Technology Development Review and Research Agenda. Technol. Forecast. Soc. Chang. 2020, 151, 119879. [CrossRef]

23. Bunduchi, R.; Tursunbayeva, A.; Pagliari, C. Coping with Institutional Complexity: Intersecting Logics and Dissonant Visions in a Nation-Wide Healthcare IT Implementation Project. Inf. Technol. People 2020, 33, 311-339. [CrossRef]

24. Verganti, R. Design Driven Innovation: Changing the Rules of Competition by Radically Innovating What Things Mean; Harvard Business Press: Boston, MA, USA, 2009; ISBN 1422136574.

25. Orlikowski, W.J.; Gash, D.C. Technological Frames: Making Sense of Information Technology in Organizations. ACM Trans. Inf. Syst. 1994, 12, 174-207. [CrossRef]

26. Acha, V. Technology Frames: The Art of Perspective and Interpretation in Strategy. SPRU Work. Pap. Ser. 2004, $44,23$.

27. Iansiti, M.; Levien, R. The Keystone Advantage; Harvard Business School Press: Boston, MA, USA, 2004.

28. Gawer, A.; Cusumano, M.A. Platform Leadership: How Intel, Microsoft, and Cisco Drive Industry Innovation; Harvard Business School Press: Boston, MA, USA, 2002; ISBN 1578515149.

29. Benford, R.D.; Snow, D.A. Framing Processes and Social Movements. An Overview and Assessment. Am. J. Sociol. 2000, 26, 611-639. [CrossRef]

30. Haas, P.M. Do Regimes Matter? Epistemic Communities and Mediterranean Pollution Control. Int. Organ. 1989, 43, $377-403$. [CrossRef]

31. Braithwaite, J.; Drahos, P. Global Business Regulation; Cambridge University Press: Cambridge, UK, 2000.

32. Weick, K.E. Sensemaking in Organizations; Sage Publications: Thousand Oaks, CA, USA, 1995.

33. Hargrave, T.; Van De Ven, A. A Collective Action Model of Innovation Institutional. Acad. Manag. Rev. 2006, 31, 864-888. [CrossRef]

34. Kaplan, S. Framing Contests: Strategy Making Under Uncertainty. Organ. Sci. 2008, 19, 729-752. [CrossRef]

35. Garud, R.; Rappa, M.A. A Socio-Cognitive Model of Technology Evolution: The Case of Cochlear Implants. Organ. Sci. 1994, 5 , 344-362. [CrossRef]

36. Gilbert, C.G. Change in the Presence of Residual Fit: Can Competing Frames Coexist? Organ. Sci. 2006, 17, 150-167. [CrossRef]

37. Tripsas, M.; Gavetti, G. Capabilities, Cognition, and Inertia: Evidence from Digital Imaging. Strateg. Manag. J. 2000, 21, 1147-1161. [CrossRef]

38. Pinch, T.J.; Bijker, W.E. The Social Construction of Facts and Artifacts: Or How the Sociology of Science and the Sociology of Technology Might Benefit Each Other. In The Social Construction of Technological Systems; MIT Press: Cambridge, MA, USA, 1987; pp. 17-50.

39. Fukami, Y.; Shimizu, T. Innovating through Standardization: How Google Leverages the Value of Open Digital Platforms. In Proceedings of the Twenty-Second Pacific Asia Conference on Information Systems, Yokohama, Japan, 26-30 June 2018; pp. 2273-2285.

40. Rochet, J.-C.; Tirole, J. Platform Competition in Two-Sided Markets. J. Eur. Econ. Assoc. 2003, 1, 990-1029. [CrossRef]

41. Parker, G.G.; Alstyne, M.W. Van Two-Sided Network Effects: A Theory of Information Product Design. Management 2005, 51, 1494-1504. [CrossRef]

42. Eisenmann, T.R.; Parker, G.; Van Alstyne, M.W. Strategies for Two-Sided Markets. Harv. Bus. Rev. 2006, 84, 92.

43. Bales, G.L.; Das, J.; Tsugawa, J.; Linke, B.; Kong, Z. Digitalization of Human Operations in the Age of Cyber Manufacturing: Sensorimotor Analysis of Manual Grinding Performance. J. Manuf. Sci. Eng. 2017, 139. [CrossRef]

44. Wartena, F.; Muskens, J.; Schmitt, L. Continua: The Impact of a Personal Telehealth Ecosystem. In Proceedings of the International Conference on eHealth, Telemedicine, and Social Medicine, eTELEMED 2009, Cancun, Mexico, 1-7 February 2009 ; pp. 13-18. 
45. Carroll, R.; Cnossen, R.; Schnell, M.; Simons, D. Continua: An Interoperable Personal Healthcare Ecosystem. IEEE Pervasive Comput. 2007, 6, 90-94. [CrossRef]

46. Aragüés, A.; Escayola, J.; Martínez, I.; Del Valle, P.; Muñoz, P.; Trigo, J.D.; García, J. Trends and Challenges of the Emerging Technologies toward Interoperability and Standardization in E-Health Communications. IEEE Commun. Mag. 2011, 49, 182-188. [CrossRef]

47. Funk, J.L.; Methe, D.T. Market- and Committee-Based Mechanisms in the Creation and Diffusion of Global Industry Standards: The Case of Mobile Communication. Res. Policy 2001, 30, 589-610. [CrossRef]

48. Simcoe, T. Delay and de jure standardization: Exploring the slowdown in Internet standards development. In Standards and Public Policy; Greenstein, S.M., Stango, V., Eds.; Cambridge University Press: New York, NY, USA, 2006; pp. 260-295, ISBN 9780511493249.

49. Farrell, J.; Simcoe, T. Choosing the Rules for Formal Standardization. RAND J. Econ. 2012, 43, 235-252. [CrossRef]

50. MacKenzie, D.; Wajcman, J. The Social Shaping of Technology, 2nd ed.; Open University Press: Buckingham, UK, 1999 ; ISBN 9781316691489.

51. Büth, L.; Blume, S.; Posselt, G.; Herrmann, C. Training Concept for and with Digitalization in Learning Factories: An Energy Efficiency Training Case. Procedia Manuf. 2018, 23, 171-176. [CrossRef]

52. Bücking, M.; Steinhart, H. Headspace GC and Sensory Analysis Characterization of the Influence of Different Milk Additives on the Flavor Release of Coffee Beverages. J. Agric. Food Chem. 2002, 50, 1529-1534. [CrossRef] [PubMed]

53. Buffo, R.A.; Cardelli-Freire, C. Coffee Flavour: An Overview. Flavour Fragr. J. 2004, 19, 99-104. [CrossRef]

54. Sunarharum, W.B.; Williams, D.J.; Smyth, H.E. Complexity of Coffee Flavor: A Compositional and Sensory Perspective. Food Res. Int. 2014, 62, 315-325. [CrossRef]

55. Caprioli, G.; Cortese, M.; Sagratini, G.; Vittori, S. The Influence of Different Types of Preparation (Espresso and Brew) on Coffee Aroma and Main Bioactive Constituents. Int. J. Food Sci. Nutr. 2015, 66, 505-513. [CrossRef]

56. Bhumiratana, N.; Adhikari, K.; Chambers, E. Evolution of Sensory Aroma Attributes from Coffee Beans to Brewed Coffee. LWT-Food Sci. Technol. 2011, 44, 2185-2192. [CrossRef]

57. Czerny, M.; Mayer, F.; Grosch, W. Sensory Study on the Character Impact Odorants of Roasted Arabica Coffee. J. Agric. Food Chem. 1999, 47, 695-699. [CrossRef] [PubMed]

58. Czerny, M.; Grosch, W. Potent Odorants of Raw Arabica Coffee. Their Changes during Roasting. J. Agric. Food Chem. 2000, 48, 868-872. [CrossRef] [PubMed]

59. Scheidig, C.; Czerny, M.; Schieberle, P. Changes in Key Odorants of Raw Coffee Beans during Storage under Defined Conditions. J. Agric. Food Chem. 2007, 55, 5768-5775. [CrossRef]

60. Farah, A.; De Paulis, T.; Trugo, L.C.; Martin, P.R. Effect of Roasting on the Formation of Chlorogenic Acid Lactones in Coffee. J. Agric. Food Chem. 2005, 53, 1505-1513. [CrossRef]

61. Nebesny, E.; Budryn, G. Evaluation of Sensory Attributes of Coffee Brews from Robusta Coffee Roasted under Different Conditions. Eur. Food Res. Technol. 2006, 224, 159-165. [CrossRef]

62. Baggenstoss, J.; Poisson, L.; Kaegi, R.; Perren, R.; Escher, F. Coffee Roasting and Aroma Formation: Application of Different Time-Temperature Conditions. J. Agric. Food Chem. 2008, 56, 5836-5846. [CrossRef] [PubMed]

63. Yang, N.; Liu, C.; Liu, X.; Degn, T.K.; Munchow, M.; Fisk, I. Determination of Volatile Marker Compounds of Common Coffee Roast Defects. Food Chem. 2016, 211, 206-214. [CrossRef]

64. Dong, W.; Hu, R.; Long, Y.; Li, H.; Zhang, Y.; Zhu, K.; Chu, Z. Comparative Evaluation of the Volatile Profiles and Taste Properties of Roasted Coffee Beans as Affected by Drying Method and Detected by Electronic Nose, Electronic Tongue, and HS-SPME-GC-MS. Food Chem. 2019, 272, 723-731. [CrossRef] [PubMed]

65. Bicho, N.C.; Leitão, A.E.; Ramalho, J.C.; de Alvarenga, N.B.; Lidon, F.C. Impact of Roasting Time on the Sensory Profile of Arabica and Robusta Coffee. Ecol. Food Nutr. 2013, 52, 163-177. [CrossRef]

66. Borém, F.M.; Ribeiro, F.C.; Figueiredo, L.P.; Giomo, G.S.; Fortunato, V.A.; Isquierdo, E.P. Evaluation of the Sensory and Color Quality of Coffee Beans Stored in Hermetic Packaging. J. Stored Prod. Res. 2013, 52, 1-6. [CrossRef]

67. Di Donfrancesco, B.; Gutierrez Guzman, N.; Chambers IV, E. Comparison of Results from Cupping and Descriptive Sensory Analysis of Colombian Brewed Coffee. J. Sens. Stud. 2014, 29, 301-311. [CrossRef]

68. Chambers, E.; Sanchez, K.; Phan, U.X.T.; Miller, R.; Civille, G.V.; Di Donfrancesco, B. Development of a “Living" Lexicon for Descriptive Sensory Analysis of Brewed Coffee. J. Sens. Stud. 2016, 31, 465-480. [CrossRef]

69. Ogawa, S. Does Sticky Information Affect the Locus of Innovation? Evidence from the Japanese Convenience-Store Industry. Res. Policy 1998, 26, 777-790. [CrossRef]

70. Hippel, E. Explorations of the Impact of „Sticky“ Local Information on the Locus of Innovation. In Innovationsforschung und Technologiemanagement; Springer: Berlin/Heidelberg, Germany, 1998; pp. 275-284. [CrossRef]

71. Marti, A.; De La Peña, E. When “Old Is New Again” Artisan Baking Grows. Cereal Foods World 2018, 63, 51.

72. DeVore, P.W. Technology and science. In Essential Topics for Technology Educators; CTTE Yearbook Planning Committee, Ed.; McGraw-Hill: Glencoe, UK, 2009; pp. 2-20.

73. Skolimowski, H. The Structure of Thinking in Technology. Technol. Cult. 1966, 7, 371. [CrossRef] 
74. Adolphs, P.; Bedenbender, H.; Dirzus, D.; Ehlich, M.; Epple, U.; Hankel, M. Reference Architecture Model Industrie 4.0 (RAMI4.0); Verein Deutscher Innenieure: Dusseldorf, Germany; Zentralverband Elektrotechnik und Elektronikindustrie: Frankfurt, Germany, 2015; Available online: https://www.zvei.org/fileadmin/user_upload/Presse_und_Medien/Publikationen/2016/januar/GMA_ Status_Report_Reference_Archtitecture_Model_Industrie_4.0_RAMI_4.0_/GMA-Status-Report-RAMI-40-July-2015.pdf (accessed on 15 August 2021).

75. Ministry of Internal Affiars and Communications. Smart City Security Guideline (Ver 1.0). Tokyo, Japan. 2020. Available online: https://www.soumu.go.jp/main_sosiki/joho_tsusin/eng/presentation/pdf/Smart_City_Security_Guideline_ver1.0.pdf (accessed on 15 August 2021). 